\title{
Analisis Komunikasi Pemasaran Terpadu dan Kualitas Pelayanan terhadap Citra Perguruan Tinggi pada Keputusan Menjadi Mahasiswa S1 Ilmu Komunikasi Stikom Bandung
}

\author{
Rachmat Taufik \\ Stikom Bandung
}

\begin{abstract}
This study aims to reveal the integrated marketing communication, service quality, imagemaking college and became a student STIKOM Bandung. In addition this study also aims to determine how much influence the integrated marketing communications and service quality to the image of the university in Bandung STIKOM and determine how much influence the image of the college to the decision a student STIKOM Bandung. Locus research conducted in Bandung STIKOM through random sampling method with iterative model approach. The number of samples processed as many as 116 respondents, out of a population of 408 active students STIKOM Bandung, the academic year 2012/2013 until 2016/2017 academic year. The data collection techniques done through questionnaires, interviews and direct observation. In this study the variables studied was integrated marketing communications and service quality, which serves as the independent variables, as well as the image of the university and the decision to become a student as a dependent variable. As for the hypothesis test, path analysis and multiple regression analysis method to test the hypothesis of F test and test at level $\alpha=0.05$. SPSS. The results of data analysis and processing, concluded as follows: 1) integrated marketing communications partial effect on the image of the college. 2) The service quality is partially affected the image of the college. 3) integrated marketing communications and quality of service simultaneously affect the image of higher education, and 4) The image of the college is partially an effect on a student's decision of STIKOM Bandung.
\end{abstract}

Keywords: integrated marketing communications, quality of service, the image of the college, the decision to become a student.

\begin{abstract}
Abstrak. Penelitian ini bertujuan untuk mengetahui gambaran komunikasi pemasaran terpadu, kualitas pelayanan, citra perguruan tinggi dan keputusan menjadi mahasiswa STIKOM Bandung. Selain itu penelitian ini bertujuan pula untuk mengetahui seberapa besar pengaruh komunikasi pemasaran terpadu dan kualitas pelayanan terhadap citra perguruan tinggi di STIKOM Bandung dan mengetahui seberapa besar pengaruh citra perguruan tinggi terhadap keputusan menjadi mahasiswa STIKOM Bandung. Lokus penelitian dilaksanakan di STIKOM Bandung melalui metode random sampling dengan pendekatan model iterasi. Jumlah sampel yang diolah yaitu sebanyak 116 orang responden, dari jumlah populasi 408 mahasiswa aktif STIKOM Bandung, tahun akademik 2012/2013 sampai dengan tahun akademik 2016/2017. Adapun teknik pengumpulan data dilakukan melalui angket, wawancara dan observasi langsung. Dalam penelitian ini variabel yang diteliti adalah komunikasi pemasaran terpadu dan kualitas pelayanan, yang berfungsi sebagai variabel bebas, serta citra perguruan tinggi dan keputusan menjadi mahasiswa sebagai variabel terikat. Adapun untuk menguji hipotesis digunakan analisis jalur dan Metode analisis regresi berganda untuk menguji hipotesis digunakan uji $\mathrm{F}$ dan uji $\mathrm{t}$ pada tingkat $\alpha=0,05$. dengan bantuan program SPSS. Hasil pengolahan dan analisis data, menghasilkan kesimpulan sebagai berikut: 1) Komunikasi pemasaran terpadu berpengaruh secara parsial terhadap citra perguruan tinggi. 2) Kualitas pelayanan berpengaruh secara parsial terhadap citra perguruan tinggi. 3) Komunikasi pemasaran terpadu dan kualitas pelayanan secara simultan berpengaruh terhadap citra perguruan tinggi, dan 4) Citra perguruan tinggi secara parsial berpengaruh terhadap keputusan menjadi mahasiswa STIKOM Bandung.
\end{abstract}

Kata kunci: Komunikasi pemasaran terpadu, kualitas pelayanan, citra perguruan tinggi, keputusan menjadi mahasiswa

\section{A. PENDAHULUAN}

\section{Latar Belakang Penelitian}

Salah satu indikator kemajuan suatu bangsa adalah banyaknya jumlah outcome lulusan sarjana yang dibarengi dengan mutu sumber daya manusia yang berdaya saing tinggi. Hal ini menandakan bahwa kualitas pendidikan di Indonesia telah 
menghasilkan sumber daya manusia yang yang kreatif, inovatif dan berwawasan ilmu pengetahuan, riset teknologi, budaya dan seni. Salah satu lembaga pendidikan formal tinggi yang diberi tugas untuk menghasilkan sumberdaya manusia tersebut adalah perguruan tinggi.

Perguruan tinggi pada dasarnya senantiasa meningkatkan mutu yang dimilikinya setiap waktu, agar dapat mencetak sumberdaya manusia yang unggul. Terlebih lagi di era globalisasi saat ini yang ditandai dengan semakin ketatnya persaingan di segala bidang. Lembaga pendidikan dituntut mampu bersaing agar dapat mempertahankan eksistensinya. Untuk dapat melihat keberhasilan suatu perguruan tinggi dalam meningkatkan mutu yang dimilikinya, hal tersebut dapat dilihat dari indeks prestasi kumulatif oleh tiap-tiap mahasiswa yang bersangkutan selama masa pendidikan. Dimana hal tersebut bersumber dari kinerja dan kualitas layanan perguruan tinggi.

Menurut Nasution (2004:57), bahwa untuk mengukur tingkat keberhasilan mutu pendidikan terlebih di perguruan tinggi, perlu analisis dan evaluasi kualitas layanan pendidikan itu sendiri. Kualitas layanan meliputi lima dimensi, dikemukakan oleh Parasuraman dan para ahli sebelumnya yaitu Zeithaml dan Berry, bahwa dimensi kualitas pelayanan terdiri dari reliabilitas (reliability), daya tanggap (responsiveness), jaminan (assurance), empati (empathy) serta bukti fisik (tangibles). Tuntutan kualitas perguruan tinggi telah diatur pemerintah dalam Peraturan Pemerintah (PP) No. 19 Tahun 2005 tentang Standar Nasional Pendidikan. Prasyarat untuk dapat ditetapkan sebagai perguruan tinggi yang dapat menyelenggarakan pendidikan secara efisien dan berkualitas, harus memenuhi standar minimum kelayakan secara finansial dan melaksanakan pengelolaan perguruan tinggi berdasarkan prinsip-prinsip ekonomis, akuntabel, kredibel, dan transparan.

Namun, menurut Badan Akreditasi Nasional Perguruan Tinggi tahun 1998 dalam Suryani (2011:18), dinyatakan bahwa lembaga-lembaga perguruan tinggi harus mampu membuktikan kualitas yang tinggi yang didukung oleh akuntabilitas yang ada. Oleh karena itu, untuk memenuhi tuntutan tersebut maka perguruan tinggi melalui program-program studinya perlu memperoleh kepercayaan masyarakat dengan jaminan kualitas (quality assurance), pengendalian kualitas (quality control), dan perbaikan kualitas (quality improvement).

Pada rentang waktu 10 tahun terakhir ini, pertumbuhan jumlah PTS khususnya di Jawa Barat telah menimbulkan persaingan yang semakin ketat antar PTS lainnya untuk meningkatkan jumlah mahasiswa. Selain itu, pertumbuhan tersebut telah memberikan manfaat tersendiri bagi masyarakat karena semakin bertambahnya jumlah PTS akan semakin memberikan peluang kepada masyarakat untuk dapat dengan mudah mendapatkan akses untuk mendapatkan pendidikan sebagai upaya sebagai upaya meningkatkan taraf hidup.

Dari data EPSBED (Evaluasi Program Studi Berdasarkan Evaluasi Diri) tahun 2012, yang saat ini berubah namanya menjadi PDPT dikti, di Indonesia terdapat kurang lebih 3176 perguruan tinggi. Berikut data PTS untuk kopertis wilayah IV Jawa Barat dan Banten. dengan total program studi sebanyak 17.266. Dari jumlah program studi tersebut, 10.240 di antaranya adalah program studi penyelenggara 
jenjang pendidikan S1. Data yang lebih rinci di lingkungan Kopertis Wilayah IV, yang mencakup Provinsi Jawa Barat dan Banten, dapat dijelaskan sebagai berikut. Jumlah PTS di kedua provinsi tersebut, pada saat ini, adalah 475 (ini merupakan jumlah terbesar di antara 12 wilayah Kopertis di Indonesia), dan PTN berjumlah 7 perguruan tinggi. Jumlah program studi yang diselenggarakan oleh PTS adalah 2028, dan 1176 di antaranya adalah program studi penyelenggara jenjang S1 (Kopertis Wil. IV Jawa Barat dan Banten, 2012).

Tabel 1.1

Jumlah Perguruan Tinggi Swasta di Wilayah Kopertis IV Jawa Barat \& Banten

\begin{tabular}{|l|l|l|l|l|}
\hline Bentuk & PT & Prodi & $\begin{array}{l}\text { Mahasis } \\
\text { wa }\end{array}$ & Dosen \\
\hline Universitas & 51 & 835 & 161.963 & 8.178 \\
\hline Instititut & 6 & 51 & 15.738 & 732 \\
\hline $\begin{array}{l}\text { Sekolah } \\
\text { Tinggi }\end{array}$ & 240 & 734 & 139.431 & 6.807 \\
\hline Akademi & 148 & 221 & 38.061 & 2.081 \\
\hline Politeknik & 31 & 124 & 25.786 & 1.267 \\
\hline Jumlah & $\mathbf{4 7 6}$ & $\mathbf{1 . 9 6 5}$ & $\mathbf{3 8 0 . 9 7 9}$ & $\mathbf{1 9 . 0 6 5}$ \\
\hline
\end{tabular}

Sumber: Kopertis Wil. IV Jawa Barat dan Banten, 2012.

Pemerintah menetapkan melalui Undang-undang pendidikan nomor 20 Tahun 2003, bahwa Sistem Pendidikan Nasional sebagai kontribusi dasar hukum, telah aktif membangun mutu pendidikan nasional dengan menerapkan prinsip demokrasi, desentralisasi, otonomi, keadilan dan menjunjung tinggi hak asasi manusia. Penerepan ketentuan dalam undangundang ini diharapkan dapat mendukung segala upaya untuk memecahkan masalah pendidikan, ikut andil memberikan sumbangan yang signifikan terhadap masalah-masalah makro bangsa Indonesia.

Untuk memenuhi permintaan dan minat masyarakat pengguna PTS pada sekolah tinggi ilmu komunikasi khususnya di kota Bandung, Stikom Bandung menerima lulusan SMA/SMK dan sederajat untuk melanjutkan pendidikannya ke tingkat yang lebih tinggi. Berikut data jumlah mahasiswa Stikom Bandung dalam kurun waktu 5 tahun:

Tabel 1.3

Kondisi jumlah mahasiswa aktif Stikom Bandung dari TA. 2012-2016

\begin{tabular}{|l|l|l|l|l|l|l|}
\hline No & $\begin{array}{l}\text { Tahu } \\
\text { Akad } \\
\text { emik }\end{array}$ & PR & $\begin{array}{l}\text { Jurna } \\
\text { listik }\end{array}$ & $\begin{array}{l}\text { Man } \\
\text { kom }\end{array}$ & $\begin{array}{l}\text { Peny } \\
\text { iaran }\end{array}$ & $\begin{array}{l}\text { Jum } \\
\text { lah }\end{array}$ \\
\hline 1 & $\begin{array}{l}2012- \\
2013\end{array}$ & 24 & 12 & 20 & 35 & 91 \\
\hline 2 & $\begin{array}{l}2013- \\
2014\end{array}$ & 23 & 18 & 21 & 24 & 86 \\
\hline 3 & $\begin{array}{l}2014- \\
2015\end{array}$ & 25 & 21 & 12 & 21 & 79 \\
\hline 4 & $\begin{array}{l}2015- \\
2016\end{array}$ & 17 & 19 & 19 & 23 & 78 \\
\hline 5 & $\begin{array}{l}2016- \\
2017\end{array}$ & 28 & 15 & 16 & 25 & 84 \\
\hline \multicolumn{7}{|c|}{ Sumber: } \\
Bandung, 2016.
\end{tabular}

Dari data tersebut bisa dianalisa sementara bahwa tingkat peminat yang mendaftar ke Stikom Bandung mengalami pasang surut. Terbukti dari jumlah peminat dan pendaftar pada penerimaan mahasiswa baru setiap tahunnya dalam kurun waktu 5 tahun berturut-turut, mengalami ketimpangan jumlah rasio yang tidak seimbang.

Berdasarkan preliminary research yang dilakukan sebelumnya pada Desember 2016, terhadap 36 orang mahasiswa Stikom Bandung yang terdiri dari angkatan 2012-2016, menunjukkan bahwa minat melanjutkan ke program studi ilmu komunikasi di Stikom Bandung semakin menurun. Dari hasil survey tersebut diketahui adanya faktor-faktor yang menimbulkan penurunan minat 
mahasiswa untuk melanjutkan studi di Stikom Bandung, umumnya mereka lebih menekankan pada pentingnya promosi komunikasi pemasaran dan kualitas pelayanan, serta citra perguruan tinggi untuk meningkatkan student body setiap tahunnya.

\section{Tujuan Penelitian}

Tujuan penelitian yang ingin dicapai dalam penelitian ini adalah sebagai berikut :

1. Untuk mengetahui dan menganalisis Komunikasi Pemasaran Terpadu yang terdiri dari Advertising, Sales Promotion, Personal Selling, Public Relation \& Publicity, Interactive Marketing, Word of Mouth Marketing, Event Experiences dan Direct Marketing di Stikom Bandung.

2. Untuk mengetahui dan menganalisis pengaruh Kualitas Pelayanan terdiri dari Reliabilitas (Reliability), Daya Tanggap (Responsiveness), Jaminan (Assurance), Empati (Emphaty), dan Bukti Fisik (Tangibels) di Stikom Bandung.

3. Untuk mengetahui dan menganalisis Citra Perguruan Tinggi pada Stikom Bandung.

4. Untuk mengetahui dan menganalisis keputusan untuk menjadi mahasiswa pada Stikom Bandung.

5. Untuk mengetahui besarnya pengaruh komunikasi pemasaran terpadu terhadap citra perguruan tinggi di Stikom Bandung.

6. Untuk mengetahui besarnya pengaruh kualitas pelayan terhadap citra perguruan tinggi di Stikom Bandung.

7. Untuk mengetahui besarnya pengaruh komunikasi pemasaran terpadu dan kualitas pelayanan terhadap citra perguruan tinggi secara simultan di Stikom Bandung.

8. Untuk mengetahui besarnya pengaruh citra perguruan tinggi terhadap keputusan untuk menjadi mahasiswa di Stikom Bandung.

\section{B. STUDI PUSTAKA}

\section{Komunikasi Pemasaran Terpadu}

Integrated

Marketing

Communications (IMC) merupakan proses keterkaitan antara hubungan institusi/instansi dengan pelanggan, tujuannya adalah untuk meningkatkan nilai merek, citra dan mutu. Lebih spesifiknya, IMC adalah sebuah proses fungsional dalam membangun hubungan antar keterkaitan yang saling menguntungkan dengan pelanggan dan stakeholder, melalui pengendalian yang strategis serta mempengaruhi semua pesan yang dikirim ke masingmasing kelompok dan mendorong pergerakan data, berdialog dengan tujuan tertentu secara bersama-sama. (Duncan, 2005:7).

Secara garis besar, IMC dapat dideskripsi-kan sebagai berikut (Prisgunanto, 2006: 76-77) :

1. IMC dimulai dan bertolak dari persepsi dan aktivitas pelanggan pada produk.

2. IMC terintegrasi antara bisnis dengan kebutuhan pelanggan.

3. IMC harus terorganisasi pada semua komunikasi bisnis dalam IMC mix.

4. IMC berupaya menciptakan dialog dengan pelanggan.

5. IMC akan berupaya mencapai perilaku pelanggan ke arah kebutuhan individu.

Faktor-faktor yang mempengaruhi strategi promosi pada komunikasi pemasaran terpadu yang 
dilakukan oleh perusahaan efektif maka ada beberapa keputusan dalam merumuskan strategi promosi adalah: (1) audiens sasaran (2) tujuan komunikasi (3) pesan (4) saluran (5) anggaran (6) bauran promosi dan (7) pengukuran efektifitas promosi. (Kotler 2006: 384)

\section{Kualitas Pelayanan}

Kualitas pelayanan merupakan intepretasi dari asumsi/persepsi pelanggan terhadap keunggulan suatu layanan yang diterima dan dapat dinikmati manfaatnya sesuai harapan dan keinginannya. Pelanggan akan menilai sejauhmana kualitas layanan suatu perusahaan tersebut dinilai berkualitas atau tidak. Berdasarkan pengertian tersebut di atas dapat dikatakan bahwa kualitas pelayanan dapat diukur dengan baik, melalui perbandingan antara jasa yang ditawarkan dengan persepsi penerimaan pelanggan, apakah sudah sesuai dengan harapan pelanggan atau belum. Apabila jasa yang ditawarkan sudah memenuhi harapan konsumen maka layanan jasa tersebut dikatakan baik dan atau sebaliknya.

Parasuraman, et al,. dalam lovelock dan Wright, 2007 menyebut lima dimensi penting yang menentukan tingkat service quality yaitu ;

1. Dimensi Tangible (bukti langsung) adalah penampilan wujud/fisik, peralatan pendukung, dan sarana komunikasi. Misalnya keindahan interior kantor, kebersihan dan kelengkapan kantor, kerapian penampilan karyawan, keserasian tata letak kantor, kemudahan dan keamanan tempat parkir, serta kelengkapan sarana telekomunikasi.

2. Dimensi Reliability (keandalan)
Adalah kemampuan untuk melaksanakan jasa sesuai yang telah dijanjikan secara akurat dan dapat diandalkan. Misalnya terpenuhinya keinginan pelanggan dan ketepatan waktu yang diberikan.

3. Dimensi Responsiveness (daya tanggap) yaitu kesediaan untuk membantu pelanggan dan memberikan layanan seketika. Misalnya kepastian lamanya layanan dan kesiapan karyawan dalam melayani pelanggan.

4. Dimensi Assurance (jaminan) adalah pengetahuan, sopan santun, dan kemampuan karyawan untuk menimbulkan rasa percaya dan keyakinan. Misalnya kesopanan karyawan, keramahan karyawan, cara kerja karyawan, dan pengetahuan karyawan yang mendukung.

5. Dimensi Empathy (kepedulian) adalah rasa peduli dan perhatian individual yang diberikan perusahaan kepada pelanggan. Misalnya pendekatan perindividu kepada pelanggan dan terciptanya hubungan yang baik dengan pelanggan.

Menurut Payne (2000:7), kualitas jasa berkaitan dengan kemampuan sebuah organisasi untuk memenuhi atau melebihi harapan pelanggan. Ukuran kinerja adalah kualitas jasa yang dipersepsikan. Selama ini ada pendapat bahwa kualitas jasa memiliki dua komponen penting yaitu: kualitas teknis (dimensi hasil proses operasi jasa) dan kualitas fungsional (dimensi proses dalam hal ini interaksi antara pelanggan dengan penyedia jasa).

\section{Citra Perguruan Tinggi}

Menurut Jefkins dan Yadin (2003:22) menegaskan bahwa citra 
institusi/perusahaan adalah citra dari suatu organisasi dibangun secara menyeluruh, gambaran citra perusahaan/institusi bukan sekedar citra melalui produk dan pelayanannya semata. Citra institusi/perusahaan, terbentuk dari beberapa hal, seperti sejarah atau riwayat hidup perusahaan yang gemilang, kualitas produk, reputasi sebagai pencipta lapangan kerja, kesediaan turut memikul tanggung jawab sosial, dan komitmen mengadakan riset.

Pendapat lainnya, Siswanto Sutojo (2004:3) mengemukakan bahwa manfaat citra institusi yang baik dan kredibel adalah:

1. Memberikan dampak terhadap daya saing pada jangka menengah dan panjang secara berkelanjutan (min and long term sustainable competitive position).

2. Menjadi pengaman selama krisis berlangsung (an insurance for adverse times).

3. Bisa menjadi daya tarik eksekutif yang handal (attracting the best executives available).

4. Dapat meningkatkan efektivitas pada strategi pemasaran (increasing the effectiveness of marketing instruments).

5. Sebagai penghemat untuk biaya operasional (cost savings).

Citra itu sendiri dapat berakibat dan menimbulkan dampak positif dan negatif. Menurut Zhang (2009:32), dimensi atau sub variabel citra institusi/perusahaan tersebut:

1. Disukai (Likeability), merupakan kemampuan untuk disukai menunjukkan daya tarik sumber pesan di mata audience atau khalayak. Misalnya karena (keramahan dari karyawannya, perhatian karyawan secara personal, dan lain-lainnya).

2. Kompetensi (Competence) adalah dimana pengintegrasian dari pengetahuan, keterampilan, dan sikap yang memungkinkan untuk bisa melaksanakan satu cara efektif dan terarah. Diantaranya yaitu (pengetahuan karyawan, keakuratan dalam pencatatan sebuah dokumen).

3. Kualitas (Quality) adalah bagian komponen citra yang mampu memenuhi keinginan atau kebutuhan pelanggan. Misalnya sebagai contoh tentang (peralatan sarana penunjang, penampilan karyawan, kemudahan untuk berkomunikasi, dapat dipercaya, kecepatan penyelesaian layanan, kesediaan karyawan membantu masalah, kepastian dan rasa aman, karyawan yang terpercaya).

4. Kinerja (Performance) merupakan hasil dari keberhasilan

seseorang/organisasi secara keseluruhan, selama periode tertentu dalam melaksanakan tugas dibandingkan dengan berbagai kemungkinan, seperti standar hasil kerja, target atau sasaran atau kriteria yang telah ditentukan terlebih dahulu dan telah disepakati bersama. Diantaranya yaitu (kinerja usaha perusahaan, keakuratan hasil kerja karyawan).

5. Tanggung Jawab (Responsibility) merupakan sikap atas kewajiban dan tanggungjawab personal dalam melaksanakan tugas pokok dan fungsinya sebagai karyawan atau pimpinan.

\section{Perilaku Konsumen}


Perilaku konsumen adalah kegiatan dari interaksi yang dinamis antara kognisi, afeksi, perilaku, dan lingkungannya dimana manusia melakukan kegiatan pertukaran dalam hidup mereka" (J. Supranto dan N. Lima Krisna, $2007: 3$ ).

Ada 3 hal dalam definisi perilaku konsumen, yaitu :

1. Perilaku konsumen bersifat dinamis, sehingga susah diramalkan.

2. Melibatkan interaksi: kognisi, afeksi, perilaku, dan kejadian disekitar/ lingkungan konsumen.

3. Melibatkan pertukaran, seperti menukar barang milik penjual dengan uang milik pembeli.

Menurut Solomon (2011:33), mendefinisikan bahwa perilaku konsumen sebagai berikut: "It is the study of the processes involved when individuals or groups select, purchase, use, or dispose of product, service, ideas, or experiences to statisfy needs and desires".

Faktor-faktor yang mempengaruhi perilaku konsumen dapat digambarkan sebagai berikut :

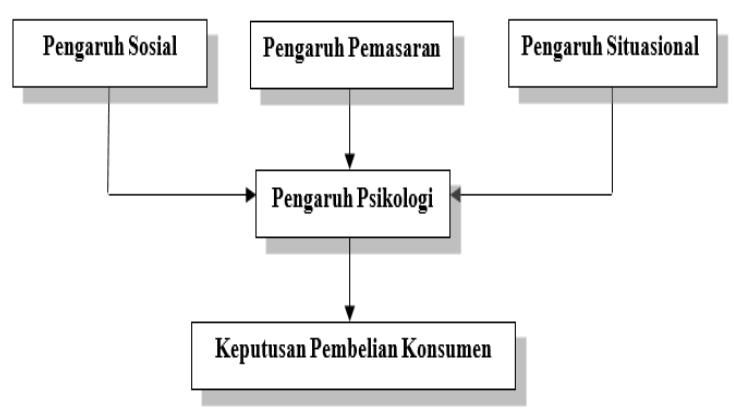

Gambar 1.1 Faktor-faktor yang mempengaruhi perilaku konsumen dalam melakukan keputusan pembelian

(Peter dan Donnelly, 2010 : 40)

\section{Keputusan Pembelian}

Secara kekhususan dan prinsipnya, pemasaran secara langsung dapat memusatkan perhatiannya pada proses pembelian secara menyeluruh, bukan pada keputusan pembelian semata. Alur proses pembelian tersebut dapat dimulai pada saat pengenalan akan kebutuhan sebelum pembelian itu dilakukan, dan berlanjut dalam waktu yang lama setelah masa pembelian dilakukan.

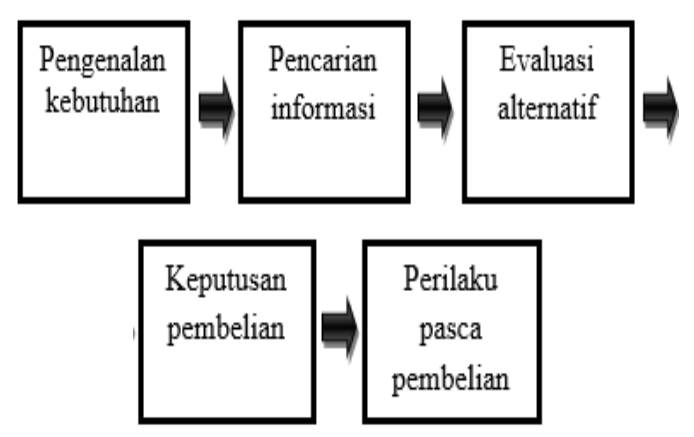

Gambar 1.2 Proses Keputusan Pembelian

(Kotler dan Amstrong, 2008:179)

\section{METODOLOGI}

PENELITIAN

Untuk menulis penelitian ini, penulis menggunakan metode penelitian sebagai berikut:

1. Teknik pengumpulan data yang digunakan dalam penelitian ini terdiri dari: kuesioner, wawancara dan studi pustaka. Data yang diperoleh langsung dari responden dikumpul-kan dengan menggunakan kuesioner dan skala likert dengan metode rating yang dijumlahkan.

2. Uji korelasi bertujuan untuk menguji hubungan antara dua variabel atau lebih yang tidak menunjukkan hubungan kausal. Uji korelasi ini tidak membedakan jenis variabel (tidak ada variabel bebas dan variabel terikat). Keeratan hubungan dinyatakan dalam 
bentuk koefisien korelasional.

3. Analisis jalur (path analysis) digunakan untuk menganalisis pola hubungan antar variabel dengan tujuan untuk mengetahui pengaruh langsung maupun tidak langsung seperangkat variabel bebas (eksogen) terhadap variabel terikat (endogen). Model path analysis yang dibicarakan adalah pola hubungan sebab akibat.

Dari tahapan di atas penulis akhirnya memperoleh informasi yang komprehensif guna menunjang serta memungkinkan untuk dilakukan penulisan pada penelitian ini.

\section{HASIL PENELITIAN}

\section{Statistik Deskriptif}

Sesuai dengan pernyataan responden, hasil olah penelitian menunjukkan bahwa rata-rata skor dari masing-masing dari variabel adalah sebagai berikut :

Tabel 4.1

Rata-rata Skor Variabel

\begin{tabular}{|c|c|c|}
\hline Variabel & Rata-Rata & Kategori \\
\hline $\begin{array}{c}\text { Komunikasi Pemasaran Terpadu } \\
(\mathrm{X} 1)\end{array}$ & 3,70 & Baik \\
\hline Kualitas Pelayanan (X2) & 3,24 & Cukup Baik \\
\hline Citra Perguruan Tinggi (Y) & 3,02 & Cukup Baik \\
\hline $\begin{array}{c}\text { Keputusan Menjadi Mahasiswa } \\
(\mathrm{Z})\end{array}$ & 2,88 & Cukup Baik \\
\hline
\end{tabular}

Tabel di atas menunjukkan skor rata-rata dari masingmasingvariabel.Variabel Komunikasi Pemasaran Terpadu (X1) mempunyai kategori baik lebih tinggi dibandingkan tiga variabel lainnya yaitu rata-rata 3,70 , namun ketiga variabel lainnya menunjukkan kategori cukup baik. Untuk memberikan gambaran yang lebih jelas mengenai hasil penghitungan statistik di atas berikut kategori penafsiran kondisi variabel penelitian.

Kriteria Penafsiran Kondisi Variabel Penelitian

\begin{tabular}{|l|l|}
\hline Rata-rata Skor & Penafsiran \\
\hline $4,2-5,0$ & Sangat Baik \\
\hline $3,4-4,1$ & Baik \\
\hline $2,6-3,3$ & Cukup Baik \\
\hline $1,8-2,5$ & Tidak Baik \\
\hline $1,0-1,7$ & Sangat tidak Baik \\
\hline \multicolumn{2}{|c|}{ Model pengontrolan kualitas (J. } \\
Supranto, 2001)
\end{tabular}

Berdasarkan tabel Kriteria penafsiran kondisi variabel penelitian, dapat dijelaskan bahwa keempat variabel tersebut di atas berada pada rata-rata skor 3,21 dengan penafsiran CukupBaik. Dari hasil penelitian ini didapat bahwa komunikasi pemasaran terpadu mempunyai pengaruh total yang dominan terhadap citra perguruan tinggi, menyusul variabel bebas lainnya yaitu kualitas pelayanan terhadap citra perguruan tinggi.

Analisis Komunikasi Pemasaran Terpadu dan Kualitas Pelayanan Terhadap Citra Perguruan Tinggi Pada Keputusan Menjadi Mahasiswa S1 Ilmu Komunikasi Stikom Bandung.

Hasil pengujian jalur (Path Analysis) dengan menggunakan software SPSS 21 diperoleh hasil sebagai berikut :

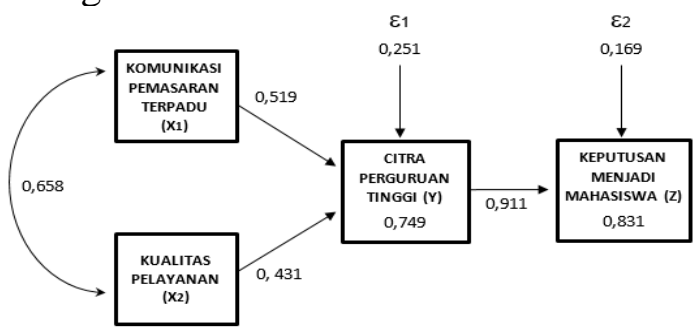

Gambar 4.1 Hasil Pengujian Jalur

Pada gambar 4.1 di atas, menunjukkan bahwa variabel Komunikasi Pemasaran Terpadu (X1 dan variabel Kualitas Pelayanan (X2) 
berpengaruh terhadap Citra Perguruan Tinggi (Y) baik secara parsial maupun simultan. Variabel Citra Perguruan Tinggi (Y) berpengaruh terhadap Keputusan Menjadi Mahasiswa (Z).

$$
\text { Besarnya }
$$

pengaruh

Komunikasi Pemasaran Terpadu (X1) dan Kualitas Pelayanan (X2) terhadap Citra Perguruan Tinggi (Y) dan Pengaruh Citra Perguruan Tinggi (Y) terhadap Keputusan Menjadi Mahasiswa (Z) yang disajikan dalam tabel sebagai berikut:

\section{Tabel 4.2}

Pengaruh Total, Pengaruh Langsung dan Pengaruh Tidak Langsung

\begin{tabular}{|l|c|c|c|c|c|}
\hline \multirow{2}{*}{ Variabel } & \multirow{2}{*}{ Langsung } & \multicolumn{3}{|c|}{ Citra Perguruan Tinggi $(Y)$} & \multicolumn{2}{|c|}{\begin{tabular}{c} 
Keputusan \\
Menjadi \\
Mahasiswa \\
\cline { 3 - 5 }
\end{tabular}} \\
\cline { 3 - 5 } & & $\mathrm{X}_{1}$ & $\mathrm{X}_{2}$ & \multicolumn{1}{|c|}{ Total } & \\
\hline $\begin{array}{l}\text { Komunikasi } \\
\text { Pemasaran } \\
\text { Terpadu }\left(\mathrm{X}_{1}\right)\end{array}$ & 0,269 & & 0,147 & 0,416 & \\
\hline $\begin{array}{l}\text { Kualitas } \\
\text { Pelayanan }\left(\mathrm{X}_{2}\right)\end{array}$ & 0,186 & 0,147 & & 0,333 & \\
\hline $\begin{array}{l}\text { Citra Perguruan } \\
\text { Tinggi }(\mathrm{Y})\end{array}$ & 0,831 & & & & 0,831 \\
\hline Pengaruh Total & & & & 0,749 & \\
\hline
\end{tabular}

Pada hasil temuan penelitian selanjutnya ini, menunjukkan bahwa komunikasi pemasaran terpadu mempunyai pengaruh langsung dan pengaruh total paling besar yaitu pengaruh langsung sebesar 0,269 dan pengaruh totalnya sebesar 0,416, dibanding kualitas pelayanan yaitu dengan pengaruh langsung sebesar 0,186 , dan pengaruh total sebesar 0,333 .

Hal ini memberikan gambaran bahwa pada penelitian selanjutnya ditemukan tentang pemilihan media promosi yang dipilih untuk publikasi Stikom Bandung melalui website, brosur, spanduk dan hot spot sudah tepat, dinilai cukup tinggi. Dari hasil uji verifikatif, responden ternyata lebih banyak memilih faktor komunikasi pemasaran terpadu sebagai pengaruh terbesar terhadap citra perguruan tinggi yang pada akhirnya menjadi pilihan minat kuliah di Stikom Bandung. Hal tersebut disebabkan karena peran media online sebagai sarana promosi dirasakan efektif, lengkap dan informatif menampilkan informasi mulai dari seputar kegiatan kampus, kurikulum, treasure study, kompetensi dosen, alumni dan program studi di Stikom Bandung.

Sementara, bila dibandingkan dengan keadaan sebelumnya, yaitu pada pra survey menyatakan bahwa publikasi/iklan Stikom Bandung jelas dan informatif, mengindikasikan bahwa belum optimalnya pemilihan media promosi Stikom Bandung dalam kegiatan penerimaan mahasiswa baru yaitu masih bersifat konvensional.

Kontribusi variabel Komunikasi Pemasaran Terpadu (X1) dan Kualitas Pelayanan (X2) terhadap Citra Perguruan Tinggi (Y) adalah sebesar 0,749 atau $74,9 \%$. Sedangkan sisanya sebesar 0,251 atau $25,1 \%$ dan merupakan kontribusi variabel lain yang tidak diteliti peneliti (variabel epsilon) diantaranya adalah adanya faktor-faktor seperti: kompetensi dosen, motivasi mahasiswa, bauran pemasaran, kepuasan pelanggan, brand image dan lain-lain.

Kontribusi variabel Citra Perguruan Tinggi (Y) terhadap Keputusan Menjadi Mahasiswa (Z) adalah sebesar 0,831 atau 83,1 \%. Sedangkan sisanya adalah sebesar 0,169 atau $16,9 \%$ dan merupakan kontribusi variabel lain yang tidak diteliti diantaranya, faktor Brand Image, kompetensi dosen, kepuasan mahasiswa, loyalitas mahasiswa, bauran pemasaran dan lain-lain.

\section{E. KESIMPULAN DAN SARAN}

\section{Kesimpulan}

Berdasarkan hasil pengolahan data serta pembahasan mengenai Pengaruh Komunikasi Pemasaran Terpadu dan 
Kualitas Pelayanan terhadap Citra Perguruan Tinggi serta dampaknya pada Keputusan Memilih Menjadi Mahasiswa, maka penulis memperoleh kesimpulan sebagai berikut :

1. Variabel Komunikasi Pemasaran Terpadu $\left(\mathrm{X}_{1}\right)$ mempunyai kategori baik lebih tinggi dibandingkan tiga variabel lainnya yaitu rata-rata 3,70 , namun ketiga variabel lainnya menunjukkan kategori cukup baik.

2. Gambaran bahwa pada penelitian ditemukan tentang pemilihan media promosi yang dipilih untuk publikasi Stikom Bandung melalui website, brosur, spanduk dan hot spot sudah tepat, dinilai cukup tinggi. Dari hasil uji verifikatif, responden ternyata lebih banyak memilih faktor komunikasi pemasaran terpadu sebagai pengaruh terbesar terhadap citra perguruan tinggi yang pada akhirnya menjadi pilihan minat kuliah di Stikom Bandung. Hal tersebut disebabkan karena peran media online sebagai sarana promosi dirasakan efektif, lengkap dan informatif menampilkan informasi mulai dari seputar kegiatan kampus, kurikulum, treasure study, kompetensi dosen, alumni dan program studi di Stikom Bandung.

3. Faktor-faktor lain yang digunakan untuk mengungkap pengaruh Komunikasi Pemasaran Terpadu dan Kualitas Pelayanan terhadap Citra Perguruan Tinggi, serta dampaknya pada Keputusan Menjadi Mahasiswa sangat terbatas dan kurang, sehingga perlu dilakukan penelitian lain yang lebih luas untuk mengungkap pengaruh masingmasing variabel tersebut secara menyeluruh.

\section{Saran}

Dengan melihat hasil penelitian dan gambaran deskriptif yang diperoleh, maka penulis memberikan saran sebagai berikut :

\section{Saran Akademis}

1. Komponen pendukung dari semua aspek yang terkait di dalamnya secara simultan dapat meningkatkan ekspektasi bagi mahasiswa serta meningkatkan kualitas jasa atas keunggulan untuk memenuhi keinginan bersama. Karena Kualitas layanan harus dimulai dari kebutuhan pelanggan dan berakhir dengan kepuasan pelanggan serta persepsi terhadap kualitas jasa. Sebagai pihak yang membeli dan mengkonsumsi jasa, pelanggan (dan bukan penyedia jasa) yang menilai tingkat kualitas jasa sebuah lembaga.

2. Peran komunikasi pemasaran terpadu dan kualitas layanan terhadap citra perguruan tinggi ditingkatkan kearah yang lebih baik dan optimal, untuk mencapai raihan jumlah mahasiswa yang diharapkan dalam setiap penerimaan mahasiswa baru setiap tahunnya.

3. Perlunya evaluasi dan analisa secara komprehensif tentang kesesuaian antara aspek intangible dengan tingkat fasilitas perkuliahan dan sarana prasarana (tangible). Hal ini dipandang perlu untuk mengatasi tingkat kesenjangan dan penurunan kepercayaan terhadap kualitas layanan 
Stikom Bandung khususnya.

4. Hasil penelitian ini didapat bahwa komunikasi pemasaran terpadu mempunyai pengaruh total yang dominan terhadap citra perguruan tinggi, menyusul variabelbebas lainnya yaitu kualitas pelayanan terhadap citra perguruan tinggi.

\section{Saran Praktis}

1. Melakukan optimalisasi dan pengembangan strategi promosi Stikom Bandung yang lebih terarah dan efektif, terutama kegiatan penerimaan mahasiswa baru setiap tahunnya. Promosi yang bersifat konvensional saat ini tidak lagi mendapat perhatian positif dari calon mahasiswa, tak terkecuali seperti media cetak (brosur, reflet, dan poster, iklan koran dan lain-lain). Untuk itu lembaga lebih mengedepankan promosi penerimaan mahasiswa melalui media online. Salah satunya adalah mengoptimalkan dan menggiatkan kembali laman Stikom Bandung dan media sosial yang selama ini dirasakan vakum.

2. Melakukan pengembangan dan evaluasi secara rutin tentang pentingnya membangun pesan komunikasi periklanan, disampaikan melalui iklan promosi bagi khalayak atau audiens, dalam membangkitkan persuasif sehingga mampu menarik perhatiannya.

3. Diperlukan peningkatan mutu akademik dan evaluasi sebagai bagian dari penilaian prestasi dan kemampuan mahasiswa dalam meningkatkan kompetensi akademik dan peningkatan kemampuan pedagogik dari para dosennya.

4. Perlunya penambahan keberagaman program studi S1Ilmu Komunikasi. Jumlah konsentrasi yang ada belum menunjukan signifikansi antara konsentrasi yang ditawarkan dengan jumlah peminatan masing-masing konsentrasi yang ada. Sehingga tidak jarang jumlah mahasiswa pada konsentrasi yang satu dengan konsentrasi lainnya terjadi ketimpangan jumlah.

\section{DAFTAR PUSTAKA}

Armstrong dan Kotler. 2008. PrinsipPrinsip Pemasaran Jilid I, Erlangga, Jakarta.

Adrian Payne. 2000. Service Marketing Pemasaran Jasa. Andi, Bandung.

Abdul Yusuf. 2013. Analisis Pengaruh Komunikasi Pemasaran Terpadu Terhadap Citra Universitas dan Implikasinya Terhadap Keputusan Menjadi Mahasiswa (Survey terhadap Mahasiswa Universitas Singaperbangsa Karawang).

Christopher et al (2008). Relationship Marketing: Bringing Quality Customer Service and Marketing Together, Bedford MK43 OAL, United Kingdom.

Duncan $\quad(2005: 7,17,21)$. Principlesof dvertising and Integrated Marketing Communication. 2nd.

Jurnal Aplikasi Manajemen Vol. 7, No. 4. November,h. 867-873. Aura Merek. Jakarta: Gramedia Pustaka Utama.

Jurnal humaniora Vol.3 No.1 April 2012. Dominikus Tulasi, Marketing Communication and Brand Awareness.

Jefkins, Frank dan Yadin. 2003, Public Relations. Edisi Revisi kelima, 
Jakarta, Erlangga.

J. Supranto dan N. Lima Krisna. 2007. Perilaku Konsumen. Mitra wacana, Media, Jakarta.

Kotler. 2004 Marketing Management: Analysis, Planing, Implementation and Control. Prentice Hall Inc.

Kotler, P and Keller (2009). Marketing Management:Analysis,Planing, Implementation and Control, Prentice Hall Inc.

Lovelock (2004), Service Marketing, Prentice Hall Inc, United States of America.

Lovelock, C. H. and Wright, L. K. 2005. Manajemen Pemasaran Jasa (Edisi Bahasa Indonesia dari Principles of Service Marketing and Management 2e). Jakarta, PT Macanan Jaya Cemerlang.

Lovelock, C. H. and Wright, L. K. 2005. Manajemen Pemasaran Jasa (Edisi Bahasa Indonesia dari Principles of Service Marketing and Management 2e). Jakarta, PT Macanan Jaya Cemerlang.

Mulyono (2008), “Analisis Pengaruh Kualitas Produk dan Kualitas Kualitas Jasa dan Kepuasan Pelanggan Eksternal Perguruan Tinggi Swata di Kota Medan". Sembiring, F. K. B. (2009).

Nasution. 2004, Manajemen Mutu Terpadu (Total Quality management), Anggota IKPI, Ghalia Indonesia: Jakarta.

Pratminingsih, A. S , "Service Quality in Higher Education: An Approach for Continous Improvement".. (2006), Jurnal Bisnis, Manajemen, \& Ekonomi. Vol. 9. No. 6 November, h. 1123-1133.

Peter, J. Paul \& James H. Donelly,Jr. 2010. Marketing Management edisi ke-5. New York: McGrawHill

Prisgunanto, Ilham. 2006. Komunikasi Pemasaran, Strategi, dan Taktik. Jakarta: Ghalia Indonesia

Renop (Rencana Operasional) Stikom Bandung 2012-2016.

SK Menteri Pendidikan dan Kebudayaan Nomor: 49/D/0/1998 tanggal 4 Juli 1998.

SK NOMOR: 02/Skep/ Stikom Bandung /E/I/2012, Tentang Perencanaan Strategis (Renstra) Stikom Bandung Tahun 2012 2016.

Siswanto Sutojo. 2004. Membangun Citra Perusahaan. Jakarta: Damar Mulia Pustaka.

Solomon, Michael R. (2011). Consumer Behavior: Buying having, and being 9th Ed. New jersey, USA: Pearson Prentice Hall.

Thurau, H. T., Langer, F. M., \& Hansen, $\mathrm{U}$ "Modelling and Managing Student Loyality: An Approach Based on the Concept of Relationship Quality". Journal of Service Research, . (2001), Vol. 3. No. 4, May. pp, 331-344.

Utomo. 2009. "Pengaruh Relationship Marketing dan Citra Perguruan Tinggi terhadap Loyalitas dengan Pemediasi Kepuasan pada Mahasiswa Perguruan Tinggi Swasta di Surabaya".

Valarie A. Zeithaml, A. Parasuraman. Edisi, berilustrasi. Penerbit, Marketing Science Institute, 2004. ISBN, 0965711439, 9780965711432 . 